\title{
MINIMALISASI DAMPAK PERKAWINAN POLIGAMI MELALUI DISEMINASI UU NO. 23 TAHUN 2004 TENTANG PENGHAPUSAN KEKERASAN DALAM RUMAH TANGGA (KDRT) PADA MASYARAKAT DESA SONGAN KECAMATAN KINTAMANI
}

\author{
oleh, \\ Ratna Artha Windari \\ Fakultas Ilmu Sosial \\ Universitas Pendidikan Ganesha
}

\begin{abstract}
ABSTRAK
Tujuan kegiatan pengabdian masyarakat ini adalah untuk meningkatkan wawasan dan pengetahuan serta kesadaran hukum khususnya bagi ibu rumah tangga serta generasi muda Desa Songan terhadap ketentuan Undang-undang Nomor 23 Tahun 2004 tentang Penghapusan Kekerasan Dalam Rumah Tangga (KDRT). sehingga dikemudian hari jika terjadi KDRT akibat perkawinan poligami masyarakat Metode pengabdian adalah "RRA dan PRA" (rural rapid appraisal dan participant rapid appraisal). Hasil kegiatan menunjukkan bahwa setelah diberikan diseminasi oleh tim Pakar Hukum dari Undiksha Singaraja masyarakat Desa Songan menjadi memiliki pengetahuan yang jelas dan utuh mengenai: (1) hakekat kekerasan dalam rumah tangga, (2) para peserta desiminasi memahami bahwa setiap orang dilarang melakukan kekerasan dalam rumah tangga terhadap orang dalam lingkup rumah tangganya, baik dengan cara kekerasan fisik, kekerasan psikis, kekerasan seksual, atau penelantaran rumah tangga, (3) upaya penanggulangan terhadap kekerasan dalam rumah tangga, (4) sanksi hukum bagi yang melakukan kekerasan rumah tangga, dan (5) implikasi perilaku KDRT yang dilakukan terhadap anak dan kaum perempuan.
\end{abstract}

Kata-kata kunci: minimalisasi, poligami, kekerasan dalam rumah tangga, desa Songan.

\begin{abstract}
The purpose of community service activities are to develop the knowledge and awareness of the law, especially for housewives and young generation Rural Songan to the provisions of Act No. 23 of 2004 on the Elimination of Domestic Violence (domestic violence). until later in case of domestic violence due to polygamy society devoted method is "RRA and PRA" (rapid rural appraisal and rapid appraisal participant). The results showed that after a given activity by a team of Legal Experts dissemination of Singaraja Undiksha villagers Songan to have a clear and complete knowledge of: (1) the nature of domestic violence, (2) the dissemination of the participants understand that each person is prohibited from domestic violence stairs to the person within the scope of the household, either by means of physical violence, psychological violence, sexual abuse, or neglect of household, (3) prevention of
\end{abstract}


domestic violence, (4) penalties for those who commit domestic violence, and (5) the implications of the behavior of domestic violence committed against children and women.

Keywords: minimization, polygamy, domestic violence, Songan village.

\section{Pendahuluan}

Masyarakat Desa Songan merupakan masyarakat yang simbolik dengan poligami. Tradisi poligami bagi masyarakat Desa Songan merupakan sesuatu yang lumrah, bahkan dianggap sebagai bentuk "kejantanan" laki-laki yang memang dominan dalam berbagai aspek. Berdasarkan data statistik Desa Songan tercatat sebanyak 89 keluarga dari 423 kepala kelurga melakoni poligami (Data Statistik Desa Songan Kintamani Tahun 2010). Menurut staf desa Songan data ini merupakan data jumlah kepala keluarga yang melaporkan diri melakukan poligami pada kepala dusun atau pada kepala desa, sedangkan yang lebih banyak tidak melaporkan diri ke-kantor kepala desa alias kawin secara adat, sehingga tidak tercatat dalam data statistik desa. Hal ini berarti, secara realitas kepala keluarga yang melakoni poligami jauh lebih banyak dibandingkan dengan jumlah yang terdapat di dalam data statistik desa. Jumlah ini disinyalir akan terus bertambah, seiring dengan semakin meningkatnya jumlah penduduk dan jumlah perkawinan yang dilangsungkan oleh kaum muda masyarakat Desa Songan. Secara sosial budaya, praktek poligami yang dilakukan oleh sebagian masyarakat Desa Songan diterima oleh masyarakat, khususnya masyarakat yang melakoni poligami. Di sisi lain salah satu dampak dari perkawinan poligami yang seringkali diabaikan dalam masyarakat adalah terjadinya kekerasan dalam rumah tangga baik terhadap anak maupun istri

Secara geografis dan sosiologis kelompok-kelompok masyarakat desa songan yang menganut kebiasaan berpoligami dapat dipetakan menjadi tiga kelompok, yaitu : (1) masyarakat yang tinggal didaerah pedalaman, seperti daerah kayuselem dan bubung. Masyarakat di daerah pedalaman yang cenderung terisolir ini mengangap poligami merupakan simbolisasi kemampuan dan keberhasilan laki-laki, serta memanfaatkan praktek poligami sebagai hiburan, karena memang daerah-daerah ini sangat minim sentuhan hiburan, (2) kelompok masyarakat yang pendidikannya masih rendah. Kelompok masyarakat ini cenderung mencoba melepaskan diri dari masalah dan beban hidup dengan cara berpoligami, (3) kelompok masyarakat yang masih sangat panatik 
terhadap punduhan (satu keturunan). Kelompok masyarakat ini menjadikan hubungan kekerabatan harus terus dipertahankan sebagaimana ikatan ketela rambat yang terus terikat.

Poligami merupakan praktek perkawinan seorang pria dengan dua atau lebih perempuan. Praktek poligami yang di beberapa daerah dianggap sebagai simbol kejantanan dan keperkasaan pria tidak terlepas dari pengaruh budaya patriarkhi yang memposisikan kaum pria lebih tinggi dibandingkan kaum perempuan. Salah satu dampak negatif yang sangat besar dari perkawinan poligami adalah terjadinya tindak kekerasan dalam rumah tangga (KDRT). Bentuk-bentuk kekerasan terhadap istri-istri dan anak-anak mereka yang dipicu dari dijalankannya perkawinan poligami adalah mulai dari tekanan psikis, penganiayaan fisik, penelantaran istri dan anak-anak, ancaman dan teror serta pengabaian hak seksual istri. Meskipun hukum mengatur secara tegas sanksi yang dikenakan kepada pelaku KDRT namun dalam sebagian besar kasus KDRT di Indonesia, khususnya pada masyarakat Desa Songan seringkali tidak dilaporkan ke pihak berwajib atau aparat kepolisian. Hal ini menimbulkan berbagai pertanyaan yang berkaitan dengan pengetahuan dan pemahaman masyarakat Desa Songan tentang hak-hak korban KDRT dan perlindungan hukumnya, sebagaimana diatur dalam UU No. 23 Tahun 2004.

Tujuan utama kegiatan pengabdian masyarakat ini adalah untuk meningkatkan wawasan dan pengetahuan serta kesadaran hukum khususnya bagi para ibu rumah tangga serta generasi muda (karang taruna) Desa Songan terhadap hukum penghapusan KDRT (UU No. 23 Tahun 2004), sehingga dikemudian hari jika terjadi KDRT akibat perkawinan poligami masyarakat sudah mengetahui tindakan hukum yang dapat dilakukan untuk melindungi kaum perempuan dan anak-anak yang mengalami hal tersebut.

Mengingat sedemikian urgennya permasalahan KDRT akibat poligami pada masyarakat Desa Songan Kintamani dan implikasinya terhadap perlindungan perempuan, maka program ini disinyalir akan dapat memberikan manfaat bagi : (1) ibu rumah tangga dan karang taruna, program pengabdian masyarakat ini akan mampu meningkatkan pengetahuan dan wawasan mereka tentang hukum penghapusan KDRT (UU No. 23 Tahun 2004), dan (2) kaum perempuan, program pengabdian 
masyarakat ini akan mampu meningkatkan pengetahuan dan wawasan mereka tentang perlindungan hukum terhadap tindak KDRT.

\section{Metode Pelaksanaan Pengabdian}

Program ini merupakan program yang bersifat terminal dalam rangka peningkatan pengetahuan dan wawasan para ibu rumah tangga dan karang taruna di Desa Songan Kecamatan Kintamani dalam memahami hukum penghapusan KDRT (UU No. 23 Tahun 2004) dengan sistem jemput bola. Untuk kepentingan pencapaian tujuan program ini, maka rancangan yang dipandang sesuai untuk dikembangkan adalah "RRA dan PRA" (rural rapid appraisal dan participant rapid appraisal). Di dalam pelaksanaannya, program ini akan mengacu pada pola sinergis antara tenaga pakar dan praktisi dari Universitas Pendidikan Ganesha. Di sisi lain, program ini juga diarahkan pada terciptanya iklim kerjasama yag kolaboratif dan demokratis dalam dimensi mutualis antara dunia perguruan tinggi dengan masyarakat secara luas di bawah koordinasi pemerintah Kabupaten setempat, khususnya dalam rangka meningkatkan pengetahuan dan wawasan ibu rumah tangga dan generasi muda (karang taruna) Desa Songan Kecamatan Kintamani secara cepat namun berkualitas bagi kepentingan pembangunan masyarakat setempat

Model pelaksanaan kegiatan ini akan dilakukan secara langsung (tatap muka) sebagaimana layaknya sistem pembelajaran yang dilakukan di sekolah atau perguruan tinggi. Lama pelaksanaan kegiatan adalah 8 (delapan) bulan yang dimulai dari tahap perencanaan, pelaksanaan sampai pada proses evaluasi dengan melibatkan ibuibu rumah tangga dan seluruh karang taruna yang ada di Desa Songan Kecamatan Kintamani, yang masing-masing banjar akan diwakili 10 orang dengan proporsi berimbang antara ibu rumah tangga dengan pemuda pemudi, sehingga jumlah pesertanya sebanyak 130 orang. Pada akhir program setiap peserta akan diberikan sertifikat sebagai tanda bukti partisipasi mereka dalam kegiatan ini. Melalui program ini, diharapkan kaum ibu rumah tangga dan juga generasi muda Desa Songan mendapatkan pengetahuan dan pemahaman yang jelas tentang UU No. 23 Tahun 2004 tentang Penghapusan Kekerasan Dalam Rumah Tangga dan menyebarluaskannya pada masing-masing banjar yang ada di Desa Songan. 


\section{Hasil dan Pembahasan}

Berdasarkan permasalahan yang dihadapi oleh masyarakat Desa Songan Kintamani dalam kaitannya dengan masalah kekerasan rumah tangga yang disebabkan karena perkawinan poligami yang tidak didasarkan pada syarat-syarat UU Perkawinan No. 1 Tahun 1974, maka pelaksanaan program pengabdian masyarakat ini telah dilakukan dalam bentuk sosialisasi kepada keluarga yang mengalami kekerasan dalam rumah tangga dan keluarga yang melakukan poligami pada masyarakat Desa Songan. Dipilihnya sasaran keluarga yang rentan terhadap kekerasan pada rumah tangga, khususnya keluarga yang melakukan poligami, karena keluarga yang melakukan poligami selama ini paling sering mengalami berbagai persoalan, termasuk kekerasan dalam rumah tangga. Di sisi lain, keluarga poligami diharapkan mampu menyebarluaskan kepada masyarakat lain yang ada di Desa Songan tentang akibat kekerasan rumah tangga, baik secara hukum maupun secara psikologis terhadap korban dan keluarga.

Diseminasi UU No. 23 Tahun 2004 Tentang Penghapusan Kekerasan Dalam Rumah Tangga (KDRT) Pada Masyarakat Desa Songan Kecamatan Kintamani ini dilaksanakan pada bulan September di Balai Banjar Toya Bungkah Kecamatan Kintamani dengan keterlibatan penuh seluruh tim yang memiliki spesifikasi kepakaran di bidang hukum. Adapun alur diseminasi UU No. 23 Tahun 2004 Tentang Penghapusan Kekerasan Dalam Rumah Tangga (KDRT) Pada Masyarakat Desa Songan Kecamatan Kintamani, 1) Tahap persiapan, yang terdiri dari tahap: (a) penyiapan bahan administrasi sesuai dengan kebutuhan pelaksanaan sosialisasi, (b) melakukan koordinasi dengan karang kepala Desa Songan dan peserta pelatihan, (c) menyiapkan materi pelatihan, (d) menyiapkan narasumber yang memiliki kompetensi sesuai dengan target dan tujuan pelatihan, dan (e) menyiapkan jadwal pelatihan selama 1 hari efektif, 2) tahap pelaksanaan, yang terdiri dari : (a) melakukan sosialisasi UU No. 23 Tahun 2004 Tentang Penghapusan Kekerasan Dalam Rumah Tangga (KDRT) Pada Masyarakat Desa Songan Kecamatan Kintamani, (b) diskusi terbatas mengenai efek Kekerasan Dalam Rumah Tangga (KDRT), dan 3) tahap evaluasi, yang terdiri dari (a) persentasi kesimpulan sosialisasi oleh peserta, (b) refleksi dan tes dari pakar, dan (c) memberikan penilaian terhadap tes yang diberikan pada peserta sosialisasi. 
Pada proses diseminasi para peserta sangat antusias mendengarkan dan memahami UU No. 23 Tahun 2004 Tentang Penghapusan Kekerasan Dalam Rumah Tangga (KDRT) yang menjadi dasar dalam menanggulangi kekerasan dalam rumah tangga. Pada proses sosialisasi terungkap sebenarnya telah banyak terjadi kejadian kekerasan rumah tangga di Desa Songan Kintamani, namun tidak sampai diajukan ke ranah hukum, baik oleh korban maupun orang yang mengetahui kejadian tersebut. Berbagai persoalan yang terjadi di dalam rumah tangga dianggap sebagai pristiwa yang bersifat "kekeluargaan" dan tidak ada payung hukum yang dapat menyentuh "hakekat kekeluargaan tersebut", sehingga mesti diselesaikan secara pribadi antar anggota keluarga. Apalagi yang melakukan kekerasan dalam rumah tangga adalah suami yang menjadi kepala keluarga, sudah dianggap sebagai sesuatu yang lazim berlaku dan tabu untuk diungkit-ungkit atau disampaikan pada orang lain.

Kekerasan dalam rumah tangga yang terjadi pada masyarakat Desa Songan Kintamani pada umumnya menimpa kaum perempuan dan anak-anak. Hal ini disebabkan karena kaum perempuan, khususnya yang melakoni "memadu" (dipoligami) menjalani "persaingan" diantara istri-istri untuk mendapatkan perhatian suami, sehingga cenderung menuruti apapun yang menjadi kemauan suami. Di sisi lain kaum perempuan secara fisik lebih lemah diabndingkan dengan kaum laki-laki. Kondisi ini dimanfaatkan oleh kaum laki-laki yang mempunyai istri lebih dari satu untuk melakukan tidakan yang semena-mena, yang pada dasarnya telah mengarah dan termasuk dalam kekerasan rumah tangga. Pada proses sosialisasi juga terekam, baik kaum perempuan, anak-anak dan laki-laki yang mengikuti proses sosialisasi tidak mengetahui adanya undang UU No. 23 Tahun 2004 Tentang Penghapusan Kekerasan Dalam Rumah Tangga (KDRT) yang menjadi jaminan perlindungan dan payung hukum terhadap kekerasan yang dilakukan oleh anggota keluarga. Mereka berasumsi persoalan rumah tangga merupakan persoalan yang bersifat kekeluargaan, sehingga tindakan apapun yang dilakukan oleh anggota keluarga terhadap anggota keluarga lainnya tidak dapat dikenakan sanksi. Asumsi ini juga melekat pada kaum perempuan dan anak-anak yang mengalami kekerasan dalam rumah tangga, sehingga tidak berani menceritakan atau melaporkan kepada pihak yang berwajib berkaitan dengan kekerasan yang dilakukan oleh suami atau orang tuanya. Bahkan, 
dianggap sebagai sesuatu yang wajar dan lumrah terjadi. Padahal dalam konsideran UU No.23 Tahun 2004 Tentang Penghapusan Kekerasan Dalam Rumah Tangga (KDRT) menyebutkan bahwa setiap warga negara berhak mendapatkan rasa aman dan bebas dari segala bentuk kekerasan sesuai dengan falsafah Pancasila dan UndangUndang Dasar Negara Republik Indonesia Tahun 1945. Disamping itu, segala bentuk kekerasan, terutama kekerasan dalam rumah tangga, merupakan pelanggaran hak asasi manusia dan kejahatan terhadap martabat kemanusiaan serta bentuk diskriminasi yang harus dihapus. Adanya konsideran dan aturan hukum ini tidak diketahui dan dipahami oleh masyarakat Desa Songan Kintamani.

Adapun jenis kekerasan rumah tangga yang dialami adalah dalam bentuk kekerasan fisik, kekerasan psikis, kekerasan seksual dan penelantaran rumah tangga. Dari proses sosialisasi terungkap kekerasan rumah tangga yang paling sering terjadi pada anggota keluarga yang melakoni poligami adalah kekerasan psikis dan penelataran rumah tangga. Hal ini disebabkan karena perkawinan poligami pada masyarakat Desa Songan yang hanya dilalui dengan proses adat, tidak mendapatkan pengakuan secara hukum nasional, kerana tidak tercatat dikantor catatan sipil. Kondisi ini menyebabkan secara hukum nasional perkawinannya dinggap tidak pernah terjadi dan anak yang terlahir dari hubungan poligami tidak mendapatkan pengakuan secara hukum nasional. Sehingga, anak yang terlahir dari poligami secara hukum nasional tidak mempunyai hak atas apa yang dimiliki oleh bapaknya. Hal ini juga berimplikasi pada perempuan yang dipoligami, dimana mereka tidak mempunyai dasar hukum yang kuat untuk menuntut suaminya, karena tidak tercatat di kantor catatan sipil. Kondisi ini menyebabkan laki-laki yang melakoni poligami merasa memiliki kekuasaan secara penuh atas istri-istri dan anak-anak yang terlahir dari proses perkawinan poligami yang dilakoni.

Negara secara hukum melalui pasal 10 UU No.23 Tahun 2004 memberikan beberapa hak terhadap korban KDRT, yakni korban berhak mendapatkan: (a) perlindungan dari pihak keluarga, kepolisian, kejaksaan, pengadilan, (b) advokat, lembaga sosial, atau pihak lainnya baik sementara maupun, (c) berdasarkan penetapan perintah perlindungan dari pengadilan; (d) pelayanan kesehatan sesuai dengan kebutuhan medis; (e) penanganan secara khusus berkaitan dengan kerahasiaan korban; 
(f) pendampingan oleh pekerja sosial dan bantuan hukum pada setiap tingkat proses pemeriksaan sesuai dengan ketentuan peraturan perundang-undangan; dan (g) pelayanan bimbingan rohani. Disamping perlindungan tersebut, apabila terjadi kekerasan dalam rumah tangga maka pasal 26 dan pasal 27 juga mengatur sebagai berikut: (a) korban berhak melaporkan secara langsung kekerasan dalam rumah tangga kepada kepolisian baik di tempat korban berada maupun di tempat kejadian perkara, (b) korban dapat memberikan kuasa kepada keluarga atau orang lain untuk melaporkan kekerasan dalam rumah tangga kepada pihak kepolisian baik di tempat korban berada maupun di tempat kejadian perkara, dan (c) dalam hal korban adalah seorang anak, laporan dapat dilakukan oleh orang tua, wali, pengasuh, atau anak yang bersangkutan yang dilaksanakan sesuai dengan ketentuan peraturan perundangundangan yang berlaku.

Setelah diberikan sosialisasi oleh tim pakar hukum dari Undiksha Singaraja, masyarakat di Desa Songan Kecamatan Kintamani dapat memahami dengan jelas UU No.23 Tahun 2004 Tentang Penghapusan Kekerasan Dalam Rumah Tangga (KDRT). Bahkan para peserta dapat mengetahui bahwa undangundang tersebut akan mengikat semua masyarakat, termasuk anggota keluarga yang melakukan kekerasan dalam rumah tangga. Para peserta juga mengetahui jenisjenis kekerasan dalam rumah tangga dan akibat hukumnya, jika terjadi kekerasan dalam rumah tangga, khususnya bagi para pelaku, walapun itu anggota keluarga. Hal ini dapat dilihat dari hasil diskusi dan evaluasi yang dilakukan oleh pakar hukum Undiksha, terhadap pengetahuan dan keterampilan peserta sosialisasi. Berdasarkan evaluasi tindak lanjut yang dilakukan, ditemukan bahwa para peserta yang mengikuti desiminasi UU No.23 Tahun 2004 Tentang Penghapusan Kekerasan Dalam Rumah Tangga (KDRT) di memiliki pengetahuan yang konsisten mengenai hakekat kekerasan dalam rumah tangga, jenis-jenis kekerasan dalam rumah tangga dan penghapusan kekerasan dalam rumah tangga serta akibat hukumnya jika melakukan kekerasan dalam rumah tangga. Dengan demikian, sesuai dengan kriteria keberhasilan program desiminasi ini, maka sosialisasi ini akan dinilai berhasil apabila mampu meningkatkan pengetahuan dan wawasan peserta sosialisasi tentang UU No.23 Tahun 2004 Tentang Penghapusan Kekerasan Dalam Rumah Tangga (KDRT). 
Berdasarkan hasil evaluasi tidak lanjut juga terekam, beberapa manfaat praktis yang diperoleh oleh peserta desiminasi Desa Songan Kecamatan Kintamani melalui sosialisasi UU No.23 Tahun 2004 Tentang Penghapusan Kekerasan Dalam Rumah Tangga (KDRT), yaitu: (1) mereka mendapatkan informasi yang jelas dan utuh mengenai hakekat kekerasan dalam rumah tangga, (2) para peserta desiminasi memahami bahwa setiap orang dilarang melakukan kekerasan dalam rumah tangga terhadap orang dalam lingkup rumah tangganya, baik dengan cara kekerasan fisik, kekerasan psikis, kekerasan seksual, atau penelantaran rumah tangga.Kekerasan fisik adalah perbuatan yang mengakibatkan rasa sakit, jatuh sakit, atau luka berat. Kekerasan psikis adalah perbuatan yang mengakibatkan ketakutan, hilangnya rasa percaya diri, hilangnya kemampuan untuk bertindak, rasa tidak berdaya, dan/atau penderitaan psikis berat pada seseorang. Kekerasan seksual meliputi: pemaksaan hubungan seksual yang dilakukan terhadap orang yang menetap dalam lingkup rumah tangga tersebut; pemaksaan hubungan seksual terhadap salah seorang dalam lingkup rumah tangganya dengan orang lain untuk tujuan komersial dan/atau tujuan tertentu, (3) upaya penanggulangan terhadap kekerasan dalam rumah tangga, (4) sanksi hukum bagi yang melakukan kekerasan rumah tangga. Para peserta memahami sanksi pidana yang akan dikenakan kepada pelaku, sebagaimana tercantum dalam pasal 44 sampai dengan pasal 49 UU No.23 Tahun 2004 dengan hukuman penjara minimal 4 (empat) bulan dan maksimal 20 tahun, serta denda mulai dari Rp. 3.000.000,- (tiga juta rupiah) hingga Rp. 500.000.000,- (lima ratus juta rupiah). Selain pidana sebagaimana tersebut diatas, hakim juga dapat menjatuhkan pidana tambahan berupa (pasal 50): (1) Pembatasan gerak pelaku baik yang bertujuan untuk menjauhkan pelaku dari korban dalam jarak dan waktu tertentu, maupun pembatasan hak-hak tertentu dari pelaku; dan (2) Penetapan pelaku mengikuti program konseling di bawah pengawasan lembaga tertentu, dan (5) Implikasi perilaku KDRT yang dilakukan oleh sang suami kepada dirinya akan menimbulkan beberapa hal seperti: (1) rasa traumatis yang dalam seperti munculnya perasaan takut dan cemas terus menerus, (2) hilangnya rasa percaya diri, (3) hilang kemampuan untuk bertindak dan menjadi tidak berdaya, (4) bisa mengakibatkan kematian akibat kekerasan fisik, pembunuhan, atau bunuh diri, (5) adanya trauma fisik berat, (6) trauma fisik dalam kehamilan yang beresiko 
terhadap ibu dan janin, (7) kehilangan akal sehat atau gangguan jiwa, (8) paranoid atau perasaan curiga terus menerus kepada orang lain, (9) gangguan psikis berat seperti depresi, sulit tidur, disfungsi seksual, kurang nafsu makan, kelelahan kronis dan lain sebagainya

\section{Penutup}

Berdasarkan hasil pelaksanaan pengabdian masyarakat pada masyarakat Desa Songan Kecamatan Kintamani, Kabupaten Bangli dapat ditarik beberapa simpulan, yaitu : (1) Masyarakat Desa Songan Kecamatan Kintamani Kabupaten Bangli, belum memiliki pengetahuan yang jelas mengenai UU No.23 Tahun 2004 Tentang Penghapusan Kekerasan Dalam Rumah Tangga (KDRT). Selama ini prilaku atau tindakan kekerasan dalam rumah tangga dianggap sebagai dianggap sebagai pristiwa yang bersifat "kekeluargaan" dan tidak ada payung hukum yang dapat menyentuh "hakekat kekeluargaan tersebut", sehingga mesti diselesaikan secara pribadi antar anggota keluarga. Apalagi yang melakukan kekerasan dalam rumah tangga adalah suami yang menjadi kepala keluarga, sudah dianggap sebagai sesuatu yang lazim berlaku dan tabu untuk diungkit-ungkit atau disampaikan pada orang lain; (2) Setelah diberikan diseminasi oleh tim, masyarakat Desa Songan memiliki pengetahuan yang jelas dan utuh mengenai (a) hakekat kekerasan dalam rumah tangga, (b) para peserta desiminasi memahami bahwa setiap orang dilarang melakukan kekerasan dalam rumah tangga terhadap orang dalam lingkup rumah tangganya, baik dengan cara kekerasan fisik, kekerasan psikis, kekerasan seksual, atau penelantaran rumah tangga, (c) upaya penanggulangan terhadap kekerasan dalam rumah tangga, (d) sanksi hukum bagi yang melakukan kekerasan rumah tangga, dan (e) implikasi perilaku KDRT yang dilakukan terhadap anak dan kaum perempuan; Program ini berhasil meningkatkan pengetahuan dan wawasan masyarakat dalam memahami hakekat kekerasan dalam rumah tangga, jenis-jenis kekerasan dalam rumah tangga, cara penanggulangan kekerasan dalam rumah tangga, sanksi hukum bagi pelaku kekerasan dalam rumah tangga dan implikasi kekerasan dalam rumah tangga terhadap korban (perempuan, maupun anak-anak).

Saran yang layak dipertimbangkan, antara lain: (1) Bagi laki-laki yang melakukan poligami, hendaknya dapat memberikan perlakukan yang adil terhadap 
semua istri dan anak-anak. Penyelesaian persoalan di dalam keluarga semestinya dilakukan secara demokratis dan terbuka, sehingga tidak menyebabkan terjadinya kekerasan dalam rumah tangga, yang pada akhirnya merugikan anak-anak dan kaum perempuan; (2) Bagi kaum perempuan yang mengalami kekerasan dalam rumah tangga, hendaknya menyampaikan penindasan yang dilakukan oleh suaminya kepada pihak yang berwajib, sehingga dapat diproses dan menjadi pelajaran bagi laki-laki yang doyan melakukan kekerasan terhadap anak dan perempuan; (3) Bagi tokoh masyarakat, hendaknya memberikan sanksi yang tegas bagi para pelaku kekerasan dalam rumah tangga yang sering dilakukan oleh laki- laki yang melakoni poligami.

\section{DAFTAR PUSTAKA}

Daweg, (1968). Babad Desa-desa di Bali. Bangli: Deppen Kabupaten Bangli

Dina. (2008). Poligami Menurut Pandangan Islam dan Siswa-Siswi SMA 38 Jakarta. (Makalah). Jakarta

Kaler, I.G.K. (1983) Butir-butir Tercecera tentang Adat Bali. Denpasar Bali Agung.

Komnas Perempuan, (2002). Peta Kekerasan Pengalaman Perempuan Indonesia, Jakarta: Ameepro

Ratna. (2007). Negara Wajib Mengatur Poligami. (Makalah). Disarikan dalam Harian Umum Warta Kota 12 Mei 2007

Panetje Gede, (1989) Aneka Catatan Tentang Hukum Adat Bali : Denpasar ; Guna Agung

Sugiyono, 2006, Metode Penelitian Kuantitatif kualitatif dan $R$ \& $D$, Bandung: ALFABETA

Yuarsi, Susi Eja, (2002). Tembok Tradisi dan Tindak Kekerasan Terhadap Perempuan, Yogyakarta: Kerjasama Pusat Studi Kependudukan dan Kebijakan UGM dengan Ford Foundation

Undang-Undang No. 1 Tahun 1974 Tentang Perkawinan, Lembaran Negara Republik Indonesia Tahun 1974 Nomor 1

Undang-Undang N0.23 Tahun 2004 Tentang Penghapusan Kekerasan Dalam Rumah Tangga, Lembaran Negara Republik Indonesia Tahun 2004 Nomor 95 